\title{
TURNAAT
}

Pendidikan Sejarah Indonesia

Online ISSN: 2622-1837

\section{NILAI EDUKASI TAMAN KOTA SIDOARJO}

\section{J. Priyanto Widodo}

\section{priwidodo@gmail.com}

Pendidikan Sejarah, STKIP PGRI Sidoarjo, Indonesia.

Abstract: Sidoarjo is an important city in East Java and it has several city parks with unique features and values. This article aims to elaborate the educational values of a city park in Sidoarjo. The data were collected trough review of literature and observation. Among several city parks in Sidoarjo, this article focusses on the Alun-alun (city square) with Jayandaru Monument as its unique feature. The

ARTICLE INFO:

Research Article

Article history:

Received 11 November 2019

Revised 16 September 2020

Accepted 12 December 2020

Published 20 December 2020

Available online 20 December

2020

(C)2020. JPSI. All rights reserved. finding suggested that the city park in Sidoarjo has several educational values: (1) cultural values, (2) identity value, (3) sense of pride, (4) love to the city, (5) diversity and (6) tolerance.

Keywords: city square, Sidoarjo, educational values

\section{PENDAHULUAN}

Taman kota memiliki pengertian tempat tinggal manusia di luar ruangan dalam beraktivitas dan berinteraksi sosial untuk mendapatkan kesenangan, kegembiraan dan kenyamanan yang menunjukkan kepribadian suatu kota atau daerah (Damayanti, 2005). Menurut Sasongko (2002) kata taman atau garden berasal dari bahasa Ibrani Gan, yang berarti melindungi atau mempertahankan dan Oden atau Eden, yang berarti kesenangan atau kegembiraan. Sedangkan menurut Damayanti (2005) pengertian taman merupakan sebidang tanah terbuka dengan luasan tertentu di dalamnya ditanami pepohonan, perdu, semak dan rerumputan hijau yang dapat dikombinasikan dengan kreasi 
dari bahan lainnya yang berfungsi untuk tempat olah raga, bersantai, bermain, dan berinteraksi sosial.

Seiring perkembangan kota dan pertumbuhan penduduknya pembangunan taman kota menjadi suatu kebutuhan penting bagi kabupaten Sidoarjo (Agustin, 2018). Implementasi UU No. 26 Tahun 2007 tentang penataan ruang, disebutkan bahwa setiap kota harus menyediakan ruang terbuka hijau (RTH) minimal 30\% dari luas kota. Pada pasal 2 ayat 2 dalam undang-undang tentang penataan ruang ini ditegaskan pula bahwa ruang terbuka hijau kota adalah bagian dari ruang-ruang terbuka (open spaces) suatu wilayah perkotaan yang di dalamnya diisi oleh tumbuhan, tanaman, dan vegetasi guna mendukung manfaat langsung atau tidak langsung yang dihasilkan oleh RTH dalam kota tersebut, di antaranya yaitu keamanan, kenyamanan, kesejahteraan, dan keindahan wilayah perkotaan tersebut. Taman kota merupakan ruang terbuka hijau yang memiliki fungsi untuk keindahan dan interaksi sosial antar warga kota (Departemen Pekerjaan Umum, 2008:3).

Taman kota pada dasarnya dapat dibagi menjadi dua yakni, taman aktif dan taman pasif (Ilmiajayanti \& Dewi, 2015). Taman aktif memiliki fungsi sebagai tempat bermain dengan dilengkapi elemen-elemen pendukung taman bermain. Sedangkan, taman pasif hanya dilengkapi elemen estetika saja sehingga pada umumnya untuk menjaga keindahan taman diberikan pagar sebagai pengaman. Taman tematik merupakan salah satu program pemerintah untuk merevitalisasi tamantaman aktif, seperti memperbaiki elemen-elemen taman, memperbanyak fasilitas untuk menunjang kegiatan-kegiatan masyarakat dan memberikan tema-tema terhadap beberapa taman kota.

Kabupaten Sidoarjo saat ini sedang giat-giatnya membangun taman-taman kota dari taman yang aktif menjadi taman tematik, salah satunya adalah Monumen Jayandaru. Program revitalisasi taman tematik dianggarkan dari anggaran pendapatan dan belanja daerah (APBD) Kabupaten Sidoarjo. Selain dari dana APBD, dana untuk membangun taman tematik juga berasal dari setoran corporate social responsibility/CSR dunia usaha dan industri.

Fokus kajian dalam artikel ini adalah nilai-nilai edukasi yang terkandung dalam taman kota di Sidoarjo, terutama alun-alun dengan monument Jayandaru yang merupakan simbol kota. Pemahasan tentan nilai edukasi taman kota beserta monumennya tentu tidak lepas dari konteks wilayah dan masyarakatnya. Oleh karenanya, pembahasan dalam kajian ini akan dimuali dengan pemaparan kondisi umum Sidoarjo beserta masyarakatnya, kemudian dilanjutkan dengan pembahasan mengenai nilai-nilai edukasi dari alun-alun Sidoarjo beserta Monumen Jayandaru.

\section{METODE}

Kajian ini berfokus pada nilai edukasi alun-alun Sidoarjo sebagai taman kota beserta Monumen Jayandaru. Data dikumpulkan melalui observasi dan kajian literatur. Literatur yang dikumpulkan terutama dari artikel ilmiah maupun data dari Badan Pusat Statistik (BPS). Data yang diperoleh kemudian dikategorikan berdasarkan tema yang muncul dan kemudian diinterpretasikan. 
Berdasarkan data yang diperoleh, peneliti kemudian menemukan beberapa temuan terkait kondisi umum Sidoarjo dan masyarakatnya, serta nilai edukasi dari alun-alun Sidoarjo dan Monumen Jayandaru.

\section{HASIL DAN PEMBAHASAN}

\section{Kabupaten Sidoarjo dan Masyarakatnya}

Kabupaten Sidoarjo sebagai salah satu penyangga ibukota provinsi Jawa Timur merupakan daerah yang mengalami proses pembangunan pesat (Damayanti, 2005; Fadilah et al., 2019). Keberhasilan ini dicapai karena berbagai potensi yang ada di wilayah Kabupaten Sidoarjo seperti dunia industri, perdagangan, pariwisata, serta usaha kecil dan menengah dapat dikemas dengan baik dan terarah (Adika, 2003). Dengan adanya berbagai potensi daerah serta dukungan sumber daya manusia yang memadai, maka dalam perkembangannya Kabupaten Sidoarjo mampu menjadi salah satu daerah strategis bagi pengembangan perekonomian wilayah regional.

Wilayah Kabupaten Sidoarjo secara keseluruhan tidak terlalu luas dibanding beberapa kabupaten/kota di Provinsi Jawa Timur namun letaknya sangat strategis (Widodo \& Fatihul, 2019). Posisinya terletak antara antara 703' dan 705' lintang selatan dan 11205' dan 11209' bujur timur. Wilayah Kabupaten Sidoarjo berbatasan dengan kabupaten dan kota besar. Sebelah utara Kota Surabaya dan Gresik, sedangkan bagian selatan perbatasan dengan Kabupaten Pasuruan. Wilayah barat perbatasan dengan Kabupaten Mojokerto, sedangkan wilayah timur Sidoarjo terbentang Selat Madura.

Topografi dataran delta Sidoarjo menurut Mudhoffir (2008) secara umum memiliki ketinggian antar o s/d 25 m, ketinggian 0-3m dengan luas 19.006 ha, meliputi 29,99\%, merupakan daerah tambak yang berada di wilayah bagian timur. Wilayah bagian tengah yang berair tawar dengan ketinggian 3-10 meter dari permukaan laut merupakan daerah pemukiman, perdagangan dan pemerintahan meliputi 40,81\%. Wilayah bagian barat dengan ketinggian 10-25 meter dari permukaan laut merupakan daerah pertanian meliputi 29,20\%.

Hidrogeologi daerah air tanah, payau, dan air asin di Sidoaro menurut Setiawati dan Hariyanto (2018) mencapai luas 16.312.69 ha. Kedalaman air tanah rata-rata 0-5 m dari permukaan tanah. Sedangkan hidrologi kabupaten Sidoarjo terletak diantara dua aliran sungai yaitu Kali Surabaya dan Kali Porong yang merupakan cabang dari Kali Brantas yang berhulu di Kota Batu. Dengan demikian wilayah Sidoarjo beriklim tropis dengan dua musim, kemarau pada bulan Juni sampai Oktober dan musim hujan pada bulan Nopember sampai Mei. Sehingga memiliki struktur tanah lebih kearah alluvial kelabu seluas 6.236,37 ha. Assosiasi alluvial kelabu dan alluvial coklat seluas 4.970,23 ha. Alluvial hidromart seluas 29.346,95 ha dan gromosal kelabu tua seluas 870,70 ha. 


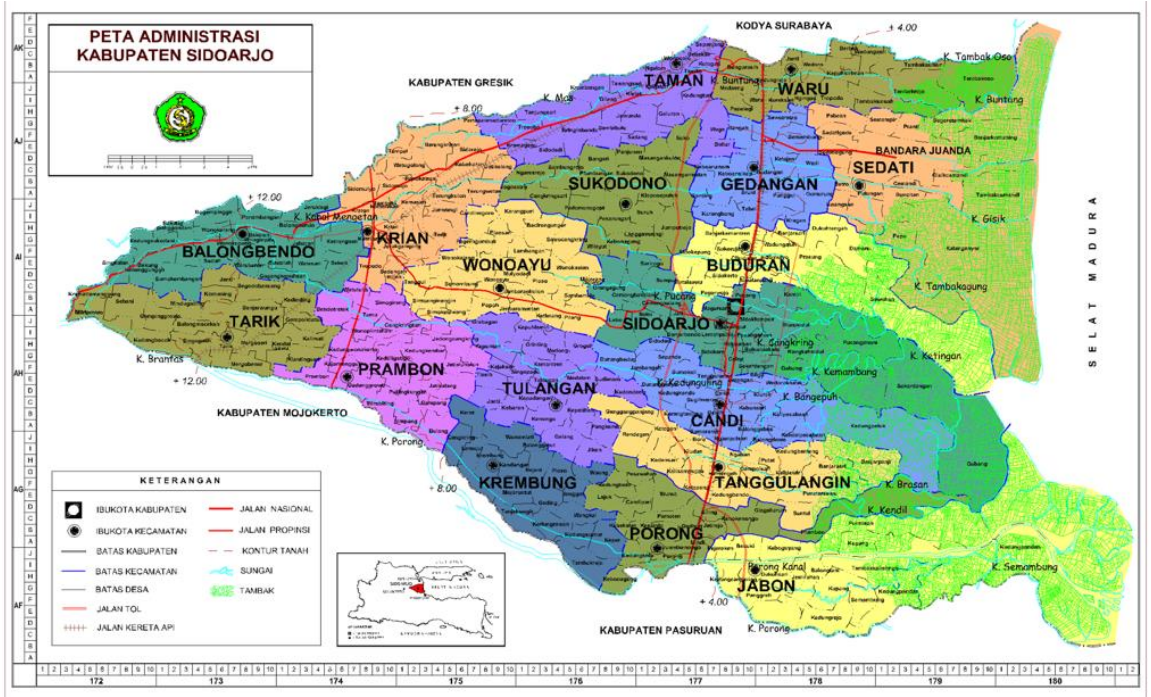

Gambar 1. Peta Administrasi Kabupaten Sidoarjo (Sumber: https://peta-kota.blogspot.com/2017/01/peta-kabupaten-sidoarjo.html)

Menurut data Badan Pusat Statistik (BPS) penduduk Kabupaten Sidoarjo pada tahun 2019 ini berjumlah 2.259.673 jiwa dengan angka pertumbuhan sekitar 1,62 persen per tahunnya. Komposisi jumlah penduduk laki-laki 1.139.295 jiwa dan penduduk perempuan berjumlah 1.120.378 jiwa (BPS, 2019). Saat ini jumlah penduduk Kabupaten Sidoarjo berada pada peringkat keempat di Jawa Timur setelah kota Surabaya, Kabupaten Malang dan Kabupaten Jember. Jumlah dan karakteristik penduduk adalah faktor penting sebab selain menjadi obyek pembangunan sekaligus sebagai pelaku pembangunan. Penduduk Sidoarjo pada umumnya merupakan warga masyarakat pendatang dari berbagai kota di dalam dan luar provinsi Jawa Timur dan dari berbagai daerah di Indonesia, sehingga memiliki latar belakang pemahaman sejarah daerah dan nilai-nilai sosial kemasyarakatan yang berbeda-beda (Hapsari \&Aulia, 2019).

\section{Taman kota di Sidoarjo}

Ada banyak taman aktif dan pasif di kabupaten Sidoarjo yang saat ini sedang dalam proses perubahan menjadi taman tematik (Sasongko, 2002). Konsepnya satu taman dengan taman lain bakal berbeda temanya. Konsep penataan taman disiapkan oleh Dinas Lingkungan Hidup dan Pertamanan Kabupaten Sidoarjo. Setidaknya ada 17 taman yang saat ini sedang dalam proses perubahan menjadi taman tematik (Mulyandari, 2011), di antaranya ada Taman Asa, Taman ASEAN, Taman Abhirama, Taman Cahaya dan Taman Alun-alun yang dilengkapi dengan Monumen Jayandaru (Agustin \& Sutejo, 2018). Monumen Jayandaru awalnya dilengkapi dengan berbagai fasilitas dan ornamen-ornamen patung yang menggambarkan tema berbagai profesi masyarakat Sidoarjo. 
Perubahan taman tematik merupakan suatu bentuk perhatian pemerintah Kabupaten Sidoarjo untuk mengubah fungsi taman yang hanya sebagai lahan hijau menjadi destinasi wisata, pendidikan, hiburan, dan tempat beraktivitas warga Sidoarjo. Dua taman yang berada di tengah kota, yakni taman cahaya dengan warna-warni lampunya dan taman alun-alun dengan Monumen Jayandaru merupakan taman tematik yang cukup fenomenal. Taman cahaya yang berada di Jalan Cokronegoro yang berada di sebelah utara alun-alun merupakan taman dengan tema cahaya atau terang. Taman ini dilengkapi dengan berbagai bentuk tanaman dan perdu berbagai bentuk dan warna cahaya lampu sebagai penerang jalan sehingga kelihatan indah dan menarik pada malam hari.

Sedangkan, taman alun-alun yang dilengkapi dengan Monumen Jayandaru merupakan taman yang paling sering dan banyak dikunjungi warga kota baik pagi, siang bahkan malam hari. Taman ini dilengkapi dengan berbagai fasilitas rekreasi, olahraga, alat-alat permainan, tempat duduk, gazebo, dan vegetasi yang cukup di sekitar atau di dalam taman. Dengan begitu taman tampak teduh, asri, serta membuat para pengunjung nyaman dan aman untuk beraktivitas di taman kota (Mulyandari, 2011; Sasongko, 2002). Monumen Jayandaru dengan ketinggian 25 meter menggambarkan identitas kabupaten Sidoarjo yang disimbolkan dengan ikan bandeng dan udang (Rizky, 2016).

Taman alun-alun yang terletak di sebelah kiri jalan raya Malang-Surabaya, tepatnya di Jalan Ahmad Yani, Sidoarjo sekarang sangat menarik pengunjung. Tata letak taman kota alun-alun Sidoarjo berbentuk taman, dipadukan dengan fasilitas olahraga dan beragam sarana permainan anak-anak (Putra, 2018). Kawasan alun-alun ini biasanya ramai pada akhir pekan, terutama pada hari minggu di mana jalan protokol sekitar alun-alun, menjadi lokasi car free day, memanjakan masyarakat Sidoarjo berolah raga tanpa terganggu lalu lalang kendaraan (Widodo \& Fatihul, 2019).

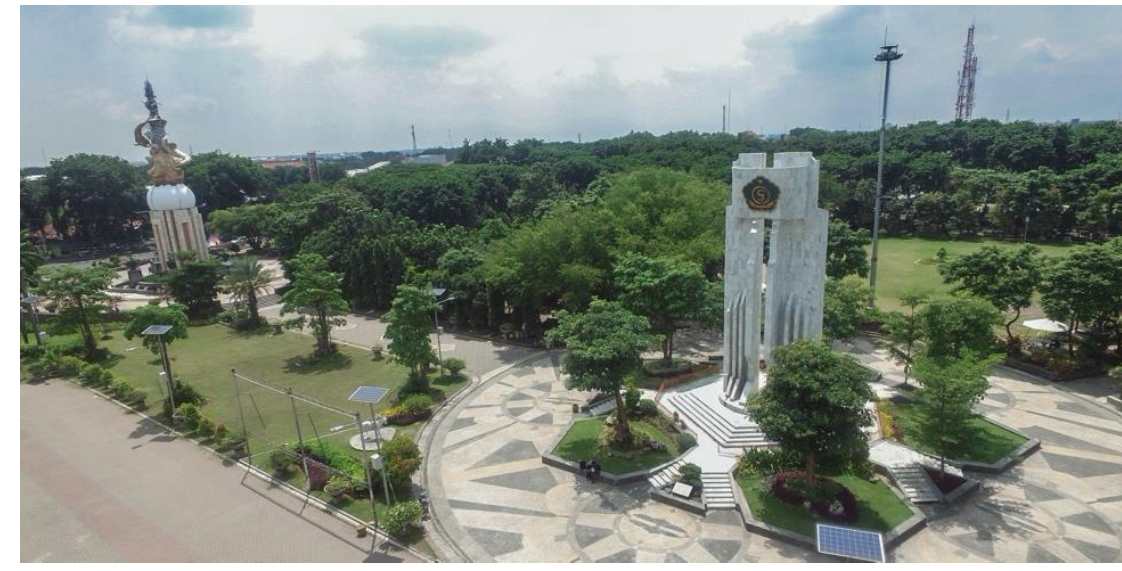

Gambar 2. Taman alun-alun dengan Monumen Jayandaru

\section{Nilai-nilai Edukasi}


Beberapa kajian terdahulu menunjukkan bahwa taman kota bisa memiliki berbagai fungsi, mulai dari fungsi edukasi, fungsi interaksi, fungsi kesehatan, fungsi perekonomian, dan sebagainya (Rini \& Afriyani, 2018; Rosawatiningsih, 2019). Pembangunan taman kota alun-alun dengan menggunakan tematik Monumen Jayandaru di Kabupaten Sidoarjo dapat memberikan nilai-nilai edukasi dalam kesejarahan daerah dan nasional, baik kepada warga asli yang lahir dan menetap di Sidoarjo dan terlebih bagi warga pendatang atau pindahan dari luar daerah. Monumen Jayandaru menggambarkan tentang kemakmuran dan kesuburan daerah delta Sidoarjo yang sebagaian besar warganya memiliki mata pencaharian sebagai petani dan nelayan (Rizky, 2016). Awalnya monumen Jayandaru dilengkapi dengan sembilan patung menyerupai manusia sebagai gambaran profesi masyarakat Sidoarjo yang diletakkan mengelilingi monumen. Namun, hal ini mendapatkan protes dari sebagian elemen masyarakat dengan alasan pemahaman agama Islam karena ciri masyarakat Sidoarjo sebagai kota santri (Rahmawan, 2017), sehingga ornamen manusia digantikan dengan udang dan bandeng yang melingkari Monumen Jayandaru sebagai bentuk ikon Sidoarjo sebagai kota dengan produk unggulan hasil lautnya.

Alun-alun Sidoarjo beserta Monumen Jayandaru memiliki beberapa nilai edukasi. Nilai itu antara lain nilai budaya, identitas, kebanggaan pada kota, cinta pada kota, kemajemukan, dan toleransi. Berikut adalah pembahasan dari masing-masing nilai tersebut.

1. Nilai budaya

Pemberian nama atau tema pada taman kota memberikan pembiasaan atau pembudayaan warga mengingat peristiwa-peristiwa sejarah lokal dan bangsanya daripada nama-nama peristiwa daerah lain (Setiawan, dkk, 2018). Benda-benda atau ornamen yang dipasang di taman kota seringkali membantu mengingatkan peristiwa masa lalu dan dapat membantu dalam mengambil keputusan untuk masa depan. Tema mengenai Jayandaru merupakan refleksi dari konsep budaya Jawa yang sangat dekat dengan sejarah dan budaya masyarakat Sidoarjo. Menurut kisah dalam pewayangan disebutkan bahwa buah Jayandaru merupakan buah yang sangat langka karena berbau harum sekali. Buah jayandaru berasal dari pohon jatiwasesa yang dimaknai sebagai sejatinya pohon atau kayu (Nautica \& Satyawan, 2019). Dalam pemahaman budaya Jawa, Jayandaru bermakna sebagai bentuk kejayaan dan kesuksesan suatu kota.

\section{Nilai identitas}

Pada dasarnya manusia memiliki rasa ingin tahu terhadap sesuatu hal yang terkait dengan dirinya. Hal yang terkait dengan tempat kelahiran dan tempat tinggal biasanya orang lebih sungguhsungguh untuk mengetahuinya. Hal ini yang dilakukan oleh pengelolah taman alun-alun Sidoarjo. Selain mendirikan Monumen Jayandaru juga disediakan informasi-informasi sejarah Kabupaten Sidoarjo. Dengan penataan taman yang menarik, asri dan hijau hendak sedang mengajak warga kota untuk kerasan berkunjung ke alun-alun. Terlebih untuk mengenal jati diri kota dan daerah-daerah melalui papan nama yang terpasang di masing-masing sudut taman (Putra, 2018). Misalnya bandara 
Juanda dan terminal bus Bungurasih seringkali dikenal sebagai wilayah Surabaya padahal menjadi wilayah Sidoarjo. Dalam hal ini Monumen Jayandaru yang menjadi simbol kota juga menunjukkan identitas khas dari Sidorjo, terutama dengan produk lautnya.

3. Nilai kebanggan pada kota

Proses perkembangan wilayah Sidoarjo seiring dengan pertambahan penduduknya yang cukup tinggi dibanding kota lain di Jawa Timur. Kabupaten Sidoarjo sebagai penyangga perekonomian Surabaya banyak bediri berbagai jenis industri dan pabrik (Damayanti, 2005). Ibarat gula maka Sidoarjo menjadi kota tujuan urbanisasi bagi para pencari kerja dari berbagai daerah di Indonesia. Pertambahan penduduk bukan karena angka kelahiran penduduk asli melainkan perpindahan penduduk dari luar kota. Seiring dengan semakin maju dan sejahtera suatu kota maka mulai tumbuh rasa bangga menjadi warga kota. Kalau dulu bangga menjadi warga Surabaya sekarang tidak malu lagi bilang sebagai warga Sidoarjo.

Pembangunan infrakstruktur termasuk taman-taman kota membuat warga menjadi lebih nyaman dan sejahtera. Kesibukan bekerja di ruang tertutup di kantor maupun di rumah membuat warga kota ingin mencari ruang lebih terbuka dan hijau. Pertamanan di kabupaten Sidoarjo pada umumnya dibangun dengan konsep ruang hijau terbuka (RTH) sehingga dimungkinkan warga kota masuk ke dalam taman dan duduk berkelompok dengan beberapa orang. Fungsi taman sebagai aktivitas sosial diwujudkan dengan tersedianya bangku-bangku dan gazebo yang dibangun dari partisipasi dunia usaha dan industri (Widodo \& Fatihul, 2019).

Taman kota alun-alun Sidoarjo selain terdapat Monumen Jayandaru tersedia juga berbagai perlengkapan olahraga fitnes, antara lain, treadmill, squat rack, mesin eliptis, dan pijakan tangga. Warga kota yang berkunjung pagi hari sambil menikmati udara segar bisa fitnes bersama beberapa orang. Aktivias sosialnya semakin terasa sewaktu menggunakan alat olahraga yang berpasangan. Di sekitar Monumen Jayandaru ada air mancur yang bisa memberi nuansa percikan air sambil menikmati jogging memutari monumen. Ada beberapa arena bermain yang ada di sekitar taman yang digemari oleh anak-anak berupa ayunan dan tangga perosotan. Dengan kondisi dan fasilitas taman kota yang lengkap seperti diuraikan di atas bisa menimbulkan rasa kebanggaan menjadi warga kota Sidoarjo. Fasilitasnya tidak kalah dengan Kota Surabaya atau kota lainnya. Bahkan Monumen Jayandaru yang menjadi ikon dan kebanggaan warga seringkali menjadi tempat obyek swafoto maupun kelompok oleh setiap pengunjung baik dari dalam maupun luar kota.

\section{Nilai cinta pada kota}

Rasa bangga yang mendalam dan terus menerus dapat menimbulkan cinta. Rasa cinta memiliki unsur bangga dengan kelebihan dan bisa menerima kekurangannya. Dengan memiliki kebanggaan sebagai warga kota karena alasan yang positif menimbulkan rasa memiliki (sense of belonging) terhadap kota dimana kita tinggal. Sense of belonging menimbulkan rasa bertanggung jawab atau 
sense of responsibility. Seseorang bangga menjadi warga Sidoarjo karena kotanya maju seperti kota lain atau seperti kota Surabaya dapat menimbulkan rasa cinta. Kecintaan warga Sidoarjo tergambar dari peran serta dan partisipasinya dalam setiap kegiatan yang bersifat sosial dan kebersamaan, misalnya pada setiap hari Minggu pagi berkumpul di taman alun-alun melakukan kegiatan olahraga dan seni bersama dengan nama kegiatan car free day dan jualan berbagai produk unggulan masingmasing desa atau kecamatan.

Antara pukul 05.00 - 10.00 WIB, masyarakat berbondong-bondong di taman-taman kota dengan berbagai kostum mengadakan kegiatan bersama, misalnya olahraga, kesenian, senam bersama, jogging, bersepeda, badminton, musik dangdut, karaoke, musik patrol dan yang lainnya. Selain itu, ada pula anggota masyarakat yang membuka berbagai stan-stan berjualan makanan, minuman khas daerah Sidoarjo, misalnya kupang lontong dan lontong balap, bandeng presto, krupuk udang, klepon dan kue lumpur sebagai jajanan khas Sidoarjo. Selain itu, para pelaku UMKM menjual produk-produk khas Sidoarjo seperti produk-produk kulit, dan jenis-jenis industri rumah tangga yang ada di Sidoarjo.

Bentuk kecintaan warga Sidoarjo terhadap kotanya terasa dan terlihat sekali saat usai kegiatan mereka bersama-sama mengambil dan mengumpulkan sampah dan barang-barang bekas. Kegiatan bersih-bersih bersama dan mengangkut semua sampah ke dalam bak-bak truk pengangkut sampah yang disediakan Dinas Pertamanan dan Kebersihan. Sehingga jalan dan taman yang semula ada ceceran sampah dan kotoran lainnya menjadi bersih kembali dan jalan dibuka kembali untuk umum.

\section{Nilai kemajemukan}

Masyarakat Sidoarjo sejak dulu terkenal sebagai nelayan dan petani tambak dengan produknya yang terkenal udang dan bandeng, sehingga setiap tahun diadakan lomba hasil laut berupa bandeng terberat atau terpanjang. Namun, sebagai daerah tujuan urbanisasi masyarakat Sidoarjo yang terkenal sebagai masyarakat santri memiliki jiwa keterbukaan. Hal ini terkait erat dengan lingkungan di mana banyak penduduk pendatang dengan berbagai latar belakang. Masyarakat Sidoarjo pada umumnya bisa hidup harmoni dengan berbagai perndatang dan latar belakangnya. Bahkan banyak rumah tangga yang rumahnya dipakai untuk kost-kostan warga pendatang. Sehingga warga Sidoarjo pada umumnya relatif dapat menerima kemajemukan (Widodo \& Fatihul, 2019).

Berbagai kegiatan bersama di taman-taman kota terasa nyaman dan aman bagi seluruh warga kota dengan adanya sikap saling menghormati dan saling mehargai. Hal ini dapat dilihat dari berbagai kegiatan warga di taman yang jarang terjadi perkelaian, atau kehilangan. Pemerintah Kabupaten Sidoarjo telah menyiapkan tenaga khusus keamanan di masing-masing taman sebagai penjaga parkir atau juru parkir dan satuan polisi pamong praja atau satpol PP. 
Taman kota dan ruang terbuka hijau lainnya adalah ruang publik tempat berkumpulnya warga kota dengan segala macam perbedaan dan kemajemukan. Kabupaten Sidoarjo adalah kota tujuan urbanisasi sehingga warganya berasal dari berbagai perbedaan latar belakang suku, agama, ras dan antargolongan. Namun demikian, setiap hari taman kota menjadi tempat transit atau tempat menunggu orang dengan berbagai keperluan. Mulai pagi hari orang berangkat kerja ke Surabaya dan kota lainnya atau orang sedang olahraga pagi mengelilingi taman.

Pada hari minggu di taman alun-alun dengan adanya program car free day hampir semua akses jalan ditutup, padahal disekitar situ ada rumah ibadah umat Kristiani. Secara rekayasa jalan pihak kepolisian dan satpol PP telah mengatur pembagian aksesnya. Sehingga disediakan akses jalan untuk umat Kristiani yang mau pergi beribadah ke gereja di sekitar taman-taman kota. Dari sini terlihat bahwa kemajemukan warga Sidoarjo dalam menjaga kebersamaan atau keberagaman tetap terjaga dengan tertib dan teratur.

6. Nilai toleransi

Sidoarjo sebagai salah satu kota tujuan urbanisasi bertumbuh menjadi melting pot dari berbagai ragam budaya warga masyarakat. Sejak terjadinya pertumbuhan pusat-pusat industri dan pabrik sekitar tahun 1990an masyarakat Sidoarjo semakin heterogen (Adika, 2003; Widodo \& Fatihul, 2019). Namun, simbol sebagai masyarakat santri tetap melekat dan semakin moderat. Problematika kehidupan sosial masyarakat heterogen seringkali muncul namun dapat terselesaikan dengan caracara shoft dan penuh kekeluargaan.

Ada kejadian yang cukup serius pada waktu pembangunan Monumen Jayandaru di taman alun-alun tahun 2015. Monumen yang menjadi ikon kota Sidaorjo yang terletak di timur taman alunalun di tepi Jalan Ahmad Yani menjadi polemik. Sekililing monumen awalnya dilengkapi dengan sembilan patung yang menurut unsur seni sangat indah yang menggambarkan ciri khas warga Sidoarjo yang perprofesi mulai petani sawah, tambak, pengrajin, tukang, pekerja bidang industri, guru, pegawai kantor dan profesi lainnya. Tetapi, ada kelompok masyarakat agama yang menganggap patung manusia sempurna simbolik berhala dan tidak berkenan terpajang secara terbuka di taman alun-alun (Rahmawan, 2017), sehingga patung yang sebagian masyarakat menganggap sebagai simbol karya seni yang awalnya terpasang begitu indah mengelilingi monumen jayandaru diturunkan dan diganti dengan udang bandeng.

Saling menghormati keragaman budaya dan keyakinan sebagai simbol masyarakat heterogen terwujud dari cara-cara menyelesaikan konflik sosial dengan arif dan bijaksana sehingga tetap tercipta suasana kota dan masyarakat yang damai menjadi prioritas utama dalam pembangunan dan pengadaan taman kota di wilayah Sidoarjo. Saling menghormati dan menghargai antar keyakinan warga Sidoarjo terimplementasikan dalam pembangunan taman kota yang notabene dibangun dengan dana CSR perusahaan swasta. Patung-patung mirip manusia sempurna dianggap melanggar nilai-nilai keislaman dan kultur masyarakat setempat dan hal ini merupakan bagian dari kearifan lokal 
(local wisdom) masyarakat Sidoarjo. Taman tematik Jayandaru yang memiliki makna dalam bahasa Sansekerta wahyu kemenangan atau kemajuan yang diharapkan menjadi inspirasi dan motivasi bagi warga Sidoarjo untuk maju harus dimodifikasi menurut nilai-nilai dan kultur masyarakat setempat (Damayanti, 2005).

\section{SIMPULAN}

Berdasarkan hasil pembahasan dan uraian di atas, maka dapat disimpulkan hal-hal terkait dengan pembangunan taman kota di Sidoarjo yang memiliki keunikan dan kekuatan yang dapat mencerminkan budaya dan kearifan lokal. Taman kota di Sidoarjo tidak hanya sebagai tempat warga masyarakat untuk beraktivitas namun dapat menjadi sarana interaksi sosial yang dapat memupuk kebersamaan sebagai warga kota.

Taman-taman di wilayah Sidoarjo seringkali menjadi destinasi wisata warga sekitar dan juga masyarakat dari luar kota yang berkunjung ke Kabupaten Sidoarjo. Salah satu taman itu adalah taman alun-alun dengan monumen jayandaru dan keindahan lingkungannya (Damayanti, 2005). Letaknya strategis dipinggir jalan raya Malang-Surabaya. Selain tamannya sejuk, indah, dan nyaman juga dilengkapi dengan fasilitas dan peralatan yang membuat pengunjung senang beraktivitas di taman.

Selain fungsi rekreatif tersebut, taman kota di Sidoarjo, terutama alu-alun dengan Monumen Jayandaru memiliki berbagai nilai edukasi yang penting. Nilai itu antara lain nilai budaya, identitas, kebanggaan pada kota, cinta pada kota, kemajemukan, dan toleransi. Nilai ini sebenarnya juga merupakan ceriman dari budaya lokal masyarakat di Kabupaten Sidoarjo.

\section{DAFTAR RUJUKAN}

Adika, I. N. (2003). Perkembangan wilayah pinggiran Kota Metropolitan Surabaya dan mobilitas tenaga kerja: Kasus Kabupaten Sidoarjo. Disertasi. Universitas Gadjah Mada.

Agustin, V.D., \& Sutedjo, A. (2018). Kajian Taman Abhirama dan Taman Tanjung Puri Dalam Pemanfaatannya sebagai Ruang Publik Masyarakat di Kabupaten Sidoarjo. Swara Bhumi, 5(9), 1-7.

Badan Pusat Stastistik (2019). Satu Data Untuk Pembangunan Kabupaten Sidoarjo. Sidoarjo: BPSSetiawati, D. L., \& Hariyanto, T. (2018). Penggunaan Sistem Informasi Geografis Berbasis Web untuk Pembentukan Prototipe Peta Dasar Pengairan (Studi Kasus: Kabupaten Sidoarjo). Geoid, 6(2), 152-158.

Damayanti, R. (2005). Kawasan" Pusat Kota" Dalam Perkembangan Sejarah Perkotaan Di Jawa. DIMENSI (Journal of Architecture and Built Environment). 33(1), 34-43

Hapsari, A. D., \& Aulia, B. U. (2019). Tipologi wilayah peri urban Kabupaten Sidoarjo berdasarkan aspek fisik, sosial, dan ekonomi. Jurnal Teknik ITS, 7(2), C168-C172. 
https://peta-kota.blogspot.com/2017/01/peta-kabupaten-sidoarjo.html

Ilmiajayanti, F., \& Dewi, D. I. K. (2015). Persepsi Pengguna Taman Tematik Kota Bandung Terhadap Aksesibilitas Dan Pemanfaatannya. Ruang, 1(1), 21-30.

Mulyandari, H. (2011). Pengantar Arsitektur Kota. Andi.

Mudhoffir, A. M. (2008). Berebut Kebenaran: Governmentality pada Kasus Lapindo. Disertasi. Universitas Indonesia.

Nautica, S., \& Sayatman, S. (2019). Perancangan Motif Batik dari Potensi Daerah Kabupaten Sidoarjo sebagai Cara Melestarikan dan Memperkaya Motif Batik Sidoarjo. Jurnal Sains dan Seni ITS, 8(1), 84-90.

Putra, M. A. P. (2018). Kinerja Ruang Publik Terhadap Peningkatan Kualitas Alun-Alun Sidoarjo Berdasarkan Kriteria Ruang Publik. Skripsi, Universitas Brawijaya.

Rahmawan, H. (2017). Penolakan GP Ansor terhadap Pembangunan Patung Jayandaru Di Kabupaten Sidoarjo. Jurnal Politik Muda, 6(2), 120-127.

Rini, H. S., \& Afriyani, R. W. (2018). Fungsi Edukasi Taman Kota Patih Sampun Pemalang sebagai Ruang Publik bagi Masyarakat. Sosietas, 8(2), 543-547.

Rizky, M. (2016). Opini Publik terhadap Patung Jayandaru sebagai Identitas Kabupaten Sidoarjo. Skripsi. Universitas Airlangga.

Rosawatiningsih, N. (2019). Kebijakan Pengelolaan Ruang Terbuka Hijau (RTH) Taman Flora Surabaya. The Journal of Society and Media, 3(1), 68-85.

Sasongko, P. D. (2002). Kajian Perubahan Fungsi Taman Kota di Kota Semarang. Tesis. Universitas Diponegoro

Setiawan, T., Sintaningrum, S., \& Mirandia, D. (2018). Persepsi Publik Pada Pengelolaan Taman Kota Di Kota Bandung. Jurnal Wacana Kinerja: Kajian Praktis-Akademis Kinerja dan Administrasi Pelayanan Publik, 20(1), 73-90.

Undang-Undang Republik Indonesia Nomor 26 Tahun 2007. Tentang Penataan Ruang. Widodo, J. P., and Fatihul, A. (2019). Sejarah Budidaya Rumput Laut Masyarakat Dusun Tegalsari Desa Kupang Kecamatan Jabon Kabupaten Sidoarjo Tahun 1998-2014. Stkip Pgri Sidoarjo 